\title{
IMPACT OF PARTIAL REPLACEMENT OF COTTONSEED MEAL BY NIGELLA SATIVA MEAL ON NUTRIENTS DIGESTIBILITY, RUMEN FERMENTATION, BLOOD PARAMETERS, GROWTH PERFORMANCE OF GROWING LAMBS
}

\author{
M.A.M. Abdullah and M.M. Farghaly \\ Department of Animal Production, Faculty of Agriculture, Assiut University, Assiut, Egypt.
}

\section{SUMMARY}

$\mathrm{T}$

This study was conducted to evaluate the effect of partial replacement of cotton seed meal in concentrate mixture by Nigella sativa ( $N$. sativa) meal on nutrients digestibility, rumen fermentation, blood metabolites and performance of lambs. Eighteen of healthy Farafra male lambs aged between 5 and 6 months old and had average of $27.2 \pm 1.3 \mathrm{~kg}$ body weights. The lambs were randomly assigned into three groups, 6 animals each lasted for 90 days. The experimental groups were a control group $(\mathrm{CON})$ fed basal diet containing concentrate mixture plus wheat straw and treated groups were fed basal diet plus $33.3 \%$ (T1) and 66.7\% (T2 ) as a substitution of cottonseed meal by $N$. sativa in concentrate mixture. The lambs were fed $65 \%$ of their requirements as a concentrate mixture based on NRC guidelines and the rest were covered from wheat straw which given as roughages ad libitum. Three digestible trials were conducted with twelve mature local rams, distributed into three group and using three experimental diets, $\mathrm{CON}, \mathrm{T} 1$ andT2. In growth trail body weight were recorded and daily gain were calculated. Plasma metabolites, ALT, AST enzymes, thyroid hormones (T3 and T4) and total antioxidant capacity (TAC) were determined in blood samples. In digested trail rumen liquor samples were collected to measure the protozoal count, $\mathrm{pH}$, ammonia N and total VFAs concentrations. Feed and fecal samples were analyzed using AOAC (2012). The results were statistically analyzed using of SPSS statistical package. The results refer to the body weight and daily gain in T2 group was increased as compared with $\mathrm{T} 1$ and $\mathrm{CON}$ groups. The total $\mathrm{DM}$ and $\mathrm{CP}$ intake were higher $(\mathrm{P}<0.05)$ in $\mathrm{T} 2$ group as compared with CON group. The partially substitution of cotton seed meal by N. sativa meal increased $(\mathrm{P}<0.05)$ the concentrations of NH3-N and total VFAs, while the total protozoal count in rumen fluids was decreased $(\mathrm{P}<0.05)$ as compared with CON group. Also, the plasma cholesterol and ALT enzyme was decreased $(\mathrm{P}<0.05)$ in $\mathrm{N}$. sativa meal groups compared to control group. However, T3 hormone and total antioxidant capacity (TAC) were higher $(\mathrm{P}<0.05)$ in $N$. sativa groups than control group. The nutrient digestibility was increased $(\mathrm{P}<0.05)$ with increasing substitution rate from 33.3 to $66.7 \%$ of cotton seed meal by $\mathrm{N}$. sativa meal. It can be concluded that the partial replacement of cottonseed meal in concentrate mixture by $N$. sativa can be used as an unconventional protein source in lambs' rations with no any harmful effect on performance of growing lambs..

Keywords: Nigella sativa meal, nutrients digestibility, rumen fermentation, blood metabolites, lambs, performance.

\section{INTRODUCTION}

Currently, consumers demand the safety and the quality of feeding. So, the use of feeds containing bioactive compounds such as thymol, flavonoids, saponins, limonene, thymoquinone, essential oils and others are responsible for the healthy animal product. Several efforts of research in ruminant production to identify strategy able to improve the quality of livestock product. On the other hand, one of the hot points in the advanced research is the stability of animal product against the oxidative deterioration process that limits the shelf life (Faustman et al., 2010). Herbal medicinal plant concentrated by bioactive compound in different parts, such as leaves, roots and seeds which can be used for these purpose in animal feed.

One of the herbal plants is N. sativa or black cumin. Black seed is widely grown in the Middle East and Southeast Asia, Mediterranean area and recently Eastern Europe. Black seed belongs to family Ranunculacea, which contains volatile oils, alkaloids and a variety of phytochemical compounds. The chemical composition of $N$. sativa are crude protein $38.7 \%$ crude fiber (8.4\%) and ash (4.8\%), (Babayan et al., 1978).

In addition, $N$. sativa meal is considered one of these alternatives feeds which rich in secondary compounds e.g. saponins, flavonoids, nigellone, tannins, resin, and volatile oils that could have positive influence on human and animal health. The active compound in $N$. sativa seed has been reported to have therapeutic effect including antioxidant (Kanter et al., 2003) and antimicrobial (Khan et al., 2003). Nigella sativa meal contains most of essential amino acid, with high level of minerals (Elmowalid et al., 2013). 
The addition of $N$. sativa meal in the diet improved growth performance of broilers (Guler and Ertas, 2006; Abu-Dieyeh and Abu-Darwish, 2008; Islam et al., 2016) and feed conversion and importantly decreasing feed costs and hence improved economic efficiency (Abdel-Magid et al., 2007). A few studies investigated the effect of use of $N$. sativa meal in sheep (Zanouny et al., 2013) and Mahmoud and Bendary (2014) and goat (Habeeb and El Tarabany, 2012) feeding. The level from 1 up 35\% of $N$. sativa meal had a positive impact on animal performance (El-Ghammry et al., 2002; Mohamed, 2007; El-Rahman et al., 2011)

In Egypt, ruminant rations still depend mainly on cottonseed cake as a source of protein, however due to inadequate supply with cottonseed cakes in the last few years, it is necessary to search for other oil seed crops that can produce a good quality by product which can substitute the cottonseed cake. The replacement of these meals with alternative meals may be decrease in feed cost. This study aimed to investigate the replacement of traditional source of protein (cotton seed meal) by $N$. sativa meal on growth performance, blood metabolites and rumen fermentation parameters of growing Farafra lambs.

\section{MATERIALS AND METHODS}

\section{Animals, diets and management:}

The experimental trail was carried out at the Animal Production Research Farm, Faculty of Agriculture, Assiut University, Egypt. Eighteen of Farafra male lambs (aged 5 to 6 month and had an average of $27.2 \pm$ $1.3 \mathrm{~kg}$ body weight divided into three homogenous groups $(\mathrm{n}=6)$ for 90 days. The lambs were individually housed in cages $\left(1.2 \times 1.2 \mathrm{~m}^{2}\right)$ and assigned randomly to one of three following groups, a control group $(\mathrm{CON})$ fed basal diet of concentrate mixture plus wheat straw and and treated groups (T1 and T2), they were fed basal diet plus $33.3 \%$ (T2) and $66.7 \%$ (T3) as a substitution of cotton seed meal by N. sativa meal in concentrate mixture .

The lambs were fed $65 \%$ of their requirements as a concentrate mixture based on NRC guidelines and the rest were covered from wheat straw as roughages ad libitum. Lambs were weighed at the beginning of the experiment and over two weeks to adjust the quantity of concentrate mixture. Along the experimental period, the concentrate mixture was offered for each animal individually once daily at $9.00 \mathrm{am}$. After consumption of the concentrate, wheat straw was added to lambs at $12.00 \mathrm{hr}$. taking into the consideration the forage to concentrate ratio. Residual feed was weighed in the morning next day at $8.00 \mathrm{~h}$ to calculate the individual feed intake. Drinking water was freely available to the lambs in each pen. Feed conversion ratio was calculated and expressed in terms of gram dry matter (DM) per gram body weight gain. The growth experimental periods involved of two periods, 15-days adjustment period followed by 90 days experimental period. The chemical analysis of feeds was carried out using procedures of Association of the Official Analytical Chemists (AOAC, 2012). Ingredients and chemical composition of experimental diets used in this study are shown in Table (1).

\section{Blood sampling}

At the end of the experiment about $10 \mathrm{ml}$ of blood samples were taken from the jugular vein of each lamb in tubes containing potassium ethylene diamine tetra-acetic acid (K-EDTA). The blood samples were directly centrifuged at $3000 \mathrm{rpm}$ for $15 \mathrm{~min}$ and the plasma was recovered and stored at $-20{ }^{\circ} \mathrm{C}$ until analyzed. Plasma metabolites: total protein, albumin (globulin concentration was obtained as the difference between the total protein and albumin concentration), total cholesterol, triglycerides, alanine aminotransferase (ALT), aspartate aminotransferase (AST) enzymes using assay kits supplied by Diamond, Egypt. Thyroid hormones (T3 and T4) concentrations were determined using enzyme-linked immunosorbent assay kits supplied by Biotecx, USA. The method of (Koracevic et al., 2001) is used to determine the Total antioxidant capacity (TAC).

\section{Digestibility trial:}

The digestibility trials were carried out using twelve local rams (two years old and about $52 \pm 1.25 \mathrm{~kg}$ body weight). Each digested trial lasted for 21 dayes, the first 15 days were considered as a preliminary period followed by 7 days collection period. Animals were randomly allocated into three experimental groups, each with 4 rams. The animals in group one were considered as a control, fed basal diet of concentrate mixture plus wheat straw and treated groups were substitution $33.3 \%$ (T1) or $66.7 \%$ (T2) of cotton seed meal in concentrate mixture by $N$. sativa meal. 
Egyptian J. Nutrition and Feeds (2019)

Table (1). The ingredients and chemical composition of experimental rations

\begin{tabular}{|c|c|c|c|c|c|}
\hline \multirow{2}{*}{ Ingredient ( $\%$ of ration) } & \multicolumn{3}{|c|}{ Treatments* } & \multirow{2}{*}{$\begin{array}{l}\text { Wheat } \\
\text { straw }\end{array}$} & \multirow{2}{*}{$N$ sativa meal } \\
\hline & Control & T1 & $\mathrm{T}_{2}$ & & \\
\hline Sorghum & 20 & 20 & 20 & - & \\
\hline Maize Grain & 20 & 20 & 20 & - & \\
\hline Wheat Bran & 35 & 35 & 35 & - & \\
\hline Cotton seed cake meal & 21 & 14 & 7 & - & \\
\hline Nigella sativa meal & - & 7 & 14 & - & \\
\hline Limestone & 2 & 2 & 2 & - & \\
\hline Salt & 1 & 1 & 1 & - & \\
\hline Trace mineral and vitamin premix£ & 1 & 1 & 1 & - & \\
\hline \multicolumn{6}{|l|}{ Chemical composition $(\%)$} \\
\hline $\mathrm{DM}$ & 90.58 & 90.54 & 90.50 & 95.36 & 90.35 \\
\hline $\mathrm{OM}$ & 82.84 & 83.30 & 83.76 & 84.69 & 81.60 \\
\hline $\mathrm{CP}$ & 14.02 & 14.50 & 14.94 & 3.26 & 33.3 \\
\hline $\mathrm{EE}$ & 2.90 & 3.42 & 3.93 & 1.56 & 12.75 \\
\hline $\mathrm{NDF}$ & 29.90 & 29.22 & 28.50 & 72.50 & 34.96 \\
\hline $\mathrm{ADF}$ & 12.90 & 12.23 & 11.55 & 43.92 & 22.00 \\
\hline
\end{tabular}

\section{Chemical analysis and digestion coefficients measurements:}

During the collection period of feces, the daily feed intake of concentrate mixture and wheat straw was calculated by removal of residual feed from the offered one. Samples of diets were taken, mixed and ground through $1 \mathrm{~mm}$ screen and stored for chemical analyses. Feces were collected daily and $10 \%$ of its weight were taken and dried at $60-70{ }^{\circ} \mathrm{C}$ for $24 \mathrm{hrs}$. The fecal collected samples from each animal were composited and grounded through a $1 \mathrm{~mm}$ mill screen for following chemical analysis. The chemical analyses of feed samples, and feces were conducted by using the methods of AOAC (2012).The apparent digestion coefficients of nutrients were defined by expressing the difference between the content of nutrients in both consumed feed and feces as a ratio of its intake.

\section{Rumen fermentation activities}

At the end of digestibility trial, samples of rumen contents were collected once from each ram using a stomach tube. The samples were collected 3-4 hrs after the morning feeding. These rumen liquor samples were divided into two portions, the first portion filtrated through one layer of cheese-cloth, which utilized to measure the protozoal count. The total protozoal count was carried out according to Abou El-Naga (1967). However, the second part filtrated through four layers of cheese-cloth, and then the obtained filtrate was used directly for measurement of $\mathrm{pH}$ using a digital $\mathrm{pH}$ meter, and ammonia $\mathrm{N}$ concentration according to Conway (1962) method. Only Some drops of saturated liquid of mercuric chloride were added to the filtrate to stop the microbial activity before its storage for analysis, and then the samples were kept frozen at $-20^{\circ} \mathrm{C}$ for determination total volatile fatty acids (VFAs). The total VFAs acids were measured using the procedures of Warner (1964).

\section{Statistical Analysis}

The results were statistically analyzed using of SPSS statistical package 22 (SPSS Institute, Chigaco, IL, USA). The data were assessed using the General Linear Models (GLM) procedure for analysis of variance and subjected to one-way ANOVA accompanied by Duncan's multiple range tests to detect the differences among the treatments. The data are presented as means \pm SE. Probability values less than $0.05(P<0.05)$ was considered significant.

The statistical model was as follows: $Y_{i j}=\mu+T_{i}+e_{i j}$

Where: $Y_{i j}=$ the observation $i j, \mu=$ the overll mean, $T_{i}=$ the effect due to treatment $\mathrm{i} ., e_{i j}=$ the experimental error. 


\section{RESULTS AND DISCUSSION}

\section{Lambs growth performance:}

The results in Table (2) indicate that the average body weight gain (BWG) and the average daily gain (ADG) of T2 group were higher $(\mathrm{P}<0.05)$ than $\mathrm{T} 1$ and $\mathrm{CON}$ group. Inclusion of $N$. sativa meal as alternative of cotton seed meal with rate $66.7 \%$ to diet of lambs improved average daily gain by about 11.7 and $16.8 \%$ as compared with $\mathrm{T} 1$ and control group, respectively. However, there was no difference $(\mathrm{P}>$ $0.05)$ between $\mathrm{T} 1$ and control group. The positive effect of $N$. sativa meal on growth performance may be due to its content of essential fatty acids like linolenic, oleic acid and linoleic acid that necessary for body growth (Abdel-Azeem et al., 1999; Makkar et al., 2007). Also, Retnani, et al. (2019) found that addition $N$. sativa meal to the diet do it extra palatability for the lambs which caused total dry matter and feed protein intake to be greater than those fed CON diet. According to the NRC (2006), one of the factors that could influence weight gain is the total protein obtained daily from the feed consumed. In addition, this improvement in daily gain in this study may be related to higher digestibility coefficient of almost nutrients especially the increase in CP and total DM intake (Table 4). Similarly, Abd El-Rahman et al. (2011) found that fed $20 \%$ N. sativa improved $(\mathrm{P}<0.05)$ average daily gain of Demeshgi goats compared to the CON diet. Also, Mohamed (2007) found that an improvement of camel performace fed $35 \%$ of $N$. sativa substituted control diet protein. Abdel-Magid et al. (2007) stated that substituting 30\% or $60 \%$ of the crude protein in a feed ration with $N$. sativa meal increased the average daily gain up to $10 \%$ compared with control. Also, Cherif et al. (2018) stated that the supplement of Nigella seeds improved $(\mathrm{P}<0.05)$ the growth performance of the Barbarine lamb.

Table (2). Effect of substituted cotton seed meal by $N$. sativa meal on growth performance of growing lambs

\begin{tabular}{|c|c|c|c|c|}
\hline \multirow{2}{*}{ Item } & \multicolumn{3}{|l|}{ Treatment* } & \multirow{2}{*}{$P$ value } \\
\hline & Control & $\mathrm{T} 1$ & $\mathrm{~T} 2$ & \\
\hline Initial weight (kg) & $27.33 \pm 0.33$ & $27.66 \pm 0.61$ & $27.33 \pm 0.49$ & 0.861 \\
\hline Final weight (kg) & $46.33^{b} \pm 0.33$ & $47.83^{b} \pm 1.60$ & $50.16^{\mathrm{a}} \pm 0.47$ & 0.001 \\
\hline $\mathrm{BW}$ gain $(\mathrm{kg})$ & $19.00^{\mathrm{b}} \pm 0.51$ & $20.16^{\mathrm{b}} \pm 0.16$ & $22.83^{\mathrm{a}} \pm 0.45$ & 0.001 \\
\hline Daily gain (g) & $211.11^{\mathrm{b}} \pm 5.73$ & $224.07^{\mathrm{b}} \pm 1.85$ & $253.70^{\mathrm{a}} \pm 5.30$ & 0.001 \\
\hline \multicolumn{5}{|l|}{ Feed Intake (FI, g/day) } \\
\hline DMI of concentrate & $1358.85 \pm 0.00$ & $1297.59 \pm 51.83$ & $1297.02 \pm 39.90$ & 0.500 \\
\hline DMI of wheat straw & $743.99^{b} \pm 40.18$ & $713.61^{b} \pm 64.38$ & $890.50^{\mathrm{a}} \pm 10.22$ & 0.029 \\
\hline Total DM intake & $2102.84^{\mathrm{ab}} \pm 40.18$ & $2011.20^{\mathrm{b}} \pm 55.50$ & $2175.20^{\mathrm{a}} \pm 36.39$ & 0.043 \\
\hline $\mathrm{CP}$ intake & $295.03^{\mathrm{b}} \pm 5.63$ & $291.02^{b} \pm 8.03$ & $326.81^{\mathrm{a}} \pm 5.43$ & 0.003 \\
\hline $\begin{array}{l}\text { Feed conversion ratio } \\
\text { g/g gain) }\end{array}$ & 9.96 & 8.98 & 8.57 & \\
\hline
\end{tabular}

${ }_{a, b, c}$ Means of the same row in each item with different superscripts are significantly different $(P<0.05)$.

*T1: substitution $33.3 \%$ of cotton seed meal by N. sativa meal. T2: substitution $66.7 \%$ of cotton seed meal by N. sativa meal.

The results in Table (2) indicate that the daily DM intake from wheat straw by lambs fed ration $\mathrm{T}_{2}$ was higher $(\mathrm{P}<0.05)$ by about 19.9 and $16.5 \%$ than those fed $\mathrm{T} 1$ and control groups, respectively. Also, the total $\mathrm{DM}$ and $\mathrm{CP}$ intake were increased $(\mathrm{P}<0.05)$ in $\mathrm{T}_{2}$ group as compared with control group. The improvement fed intake with increasing the level of substitution cotton seed meal by $N$. sativa meal may be due to $N$. sativa meal have been extensively used as a digestive and appetite stimulant (Cherif et al., 2018). The taste (bitter and pungent) of the $N$. sativa seeds is incurred by their phenolic compounds and essential oils (Aggarwal, 2009). Idris et al. (2014) attributed the improvement fed intake of lambs fed commercial oil of $N$. sativa to their appetizer effect. The similar results were reported by Habeeb and El-Tarabany (2012) they confirmed that the addition of Nigella to the diet of Zaraibi kids enhanced $(\mathrm{P}<0.05)$ DM intake. Abd ElGhani (2003) reported that the use of $N$. sativa meal significantly increased the average feed intake and body weight. Similarly, Cherif et al. (2018) noted that the addition of Nigella seeds to high concentrate diet enhanced $(\mathrm{P}<0.05)$ the total DM, OM, CP and NDF intakes of lambs. However, Retnani, et al. (2019) reported that supplement $N$. sativa meal to the diet of lambs at rate of 10 and $20 \%$ did not affected on dry matter (DM) intake. 
Regarding feed conversion ratio data presented in Table 2 showed that substitution of cotton seed meal by $N$. sativa meal improved feed conversion ratio by about 10.91 and $16.2 \%$ for $\mathrm{T}_{1}$ and $\mathrm{T}_{2}$ groups as compared with control, respectively. The positive effects of $N$. sativa meal supplement on average daily gain reflected on fed conversion ratios that are consistent with literature. Cherif et al. (2018) stated that the addition of Nigella seeds to high concentrate diet increased $(\mathrm{P}<0.05)$ feed conversion ratio than high rough diet with or without Nigella seeds supplement.

\section{Blood metabolites:}

The data in Table (3) revealed that there were no significant differences $(\mathrm{P}>0.05)$ in serum total protein, albumin, globulin, A/G ratio, triglycerides, AST and T3 hormone of lambs due to $N$. sativa meal diet. However, the average value of plasma cholesterol concentration and ALT of lambs fed diets with N. sativa meal were lower $(\mathrm{P}<0.05)$ than that of lambs fed control diet. Moreover, substituted cotton seed meal by $N$. sativa meal at level $33.4 \%$ in $\mathrm{T}_{1}$ group increase $(\mathrm{P}<0.05)$ glucose and $\mathrm{T}_{3}$ hormone compared with $\mathrm{T}_{2}$ and control groups. These results were confirmed by Zanouny et al. (2013) they reported that the supplementation of $N$. sativa to lambs diet decreased plasma triglycerides and plasma cholesterol concentration. Retnani, et al. (2019) indicates that the use of $N$. sativa meal in the diet did not alter the blood glucose or blood triglyceride concentrations of the lambs. The lower value of cholesterol may be attributed to the increase of thyroid gland activity (Table 3 ) as a result of $N$. sativa meal supplementation. Mohammed and Al-Suwaiegh (2016) stated that $N$. sativa can accelerate thyroid gland directly or indirectly via the pituitary gland. Thyroid hormones are very important for the metabolisms which increase the metabolic rate that can lead to enhanced amino acid utilization by fastening their metabolism. Also, Daghash et al. (1999) observed that the addition of $N$. sativa seeds on rabbit diet reduced serum cholesterol, total lipids and triglycerides concentration. The reduction in the triglycerides and cholesterol level might be due to the active ingredients in $N$. sativa such as thymoquinone and compounds like monounsaturated fatty acids that lower the cholesterol production by hepatocytes and reduce the fractional absorption of cholesterol from small intestine (Brunton, 1998). Also, Omar (2003) attributed the reduced cholesterol and triglyceride concentrations in diets containing high levels of $N$. sativa meal to unsaturated fatty acids, which may encourage the cholesterol secretion into the intestine and the oxidation of cholesterol to bile acids.

Transaminases enzymes (AST and ALT) concentrations were not significantly affected by $N$. Sativa (Table 3). The groups of lambs fed rations containing $N$. sativa meal had higher $(\mathrm{P}<0.05)$ concentration of plasma antioxidant capacity (TAC) than that of CON group. These antioxidant effects of $N$. sativa seeds might be due to the active constituents like thymoquinone, carvacole, anethole and 4- terepinol (Guler et al., 2007). Badary et al. (2003) concluded that $N$. sativa is an excellent superoxide anion scavenger for free radicals.

Table (3). Effect of substituted cotton seed meal by $N$. sativa meal in lambs ration on some blood parameters

\begin{tabular}{|c|c|c|c|c|}
\hline \multirow{2}{*}{ Item } & \multicolumn{3}{|c|}{ Treatment* } & \multirow{2}{*}{ P-value } \\
\hline & Control & T1 & $\mathrm{T} 2$ & \\
\hline Glucose (mg/dl) & $46.39^{\mathrm{b}} \pm 0.69$ & $59.71^{\mathrm{a}} \pm 1.22$ & $46.91^{\mathrm{b}} \pm 0.89$ & 0.001 \\
\hline Total protein (g/dl) & $5.72 \pm 0.13$ & $7.12 \pm 0.67$ & $7.04 \pm 0.65$ & 0.201 \\
\hline Albumin (A) (g/dl) & $2.47 \pm 0.08$ & $2.72 \pm 0.25$ & $2.73 \pm 0.23$ & 0.613 \\
\hline Globulin $(\mathrm{G})(\mathrm{g} / \mathrm{dl})$ & $3.25 \pm 0.10$ & $4.40 \pm 0.84$ & $4.31 \pm 0.44$ & 0.326 \\
\hline $\mathrm{A} / \mathrm{G}$ ratio & $0.76 \pm 0.04$ & $0.69 \pm 0.21$ & $0.64 \pm 0.04$ & 0.789 \\
\hline Cholesterol(mg/dl) & $58.56^{\mathrm{a}} \pm 2.82$ & $30.67^{\mathrm{b}} \pm 4.89$ & $29.54^{\mathrm{b}} \pm 1.49$ & 0.001 \\
\hline Triglycerides (mg/dL) & $177.36 \pm 4.96$ & $160.18 \pm 4.87$ & $159.64 \pm 6.41$ & 0.086 \\
\hline $\operatorname{ALT}(\mathrm{U} / \mathrm{l})$ & $15.12^{\mathrm{a}} \pm 1.65$ & $10.75^{\mathrm{b}} \pm 0.24$ & $7.63^{b} \pm 0.61$ & 0.015 \\
\hline AST(U/l) & $36.78 \pm 0.76$ & $39.29 \pm 7.76$ & $36.88 \pm 6.93$ & 0.946 \\
\hline T3 (ng/ml) & $2.85^{\mathrm{b}} \pm 0.08$ & $3.58^{\mathrm{a}} \pm 0.01$ & $3.27^{\mathrm{ab}} \pm 0.03$ & 0.071 \\
\hline $\mathrm{T} 4(\mu \mathrm{g} / \mathrm{dl})$ & $15.33 \pm 1.02$ & $17.03 \pm 0.09$ & $15.73 \pm 0.92$ & 0.350 \\
\hline TAC (mmol/L) & $0.75^{\mathrm{b}} \pm 0.01$ & $0.88^{\mathrm{a}} \pm 0.01$ & $0.93^{\mathrm{a}} \pm 0.02$ & 0.001 \\
\hline
\end{tabular}




\section{Nutrient digestibility coefficients}

Inclusion of $N$. sativa meal as partially alternative of cotton seed meal to diet of lambs improved (P $<0.05$ ) nutrients digestibility as compared with control group (Table 4). Also, it could be noticed that the nutrient digestibility was increased $(\mathrm{P}<0.05)$ with increasing substitution rate from 33.3 to $66.7 \%$ for cotton seed meal by $N$. sativa meal. Nigella sativa has antibacterial characteristics (Bita et al., 2012). Therefore, Nigella sativa may modulate microorganisms of rumen and their capabilities of rumen digestion. Lewis (1980) reported that the addition of $N$. sativa in feed heightened bile flow rate results in enhanced emulsification that activates the pancreatic lipases, which then aid in fat digestion and absorption of fat solvable vitamins. Jamroz and Kamel (2002) noticed a stimulating effect of black seeds on digestive system, resulting in superior absorption and performance. The results of our study agreement with finding by AbdelMagid et al. (2007) found that substitution $30 \%$ or $60 \%$ of soybean meal by $N$. sativa meal in growing calves rations showed specific improvement in nutrients digestibility. Aslo, Retnani, et al. (2019) found that addition $N$. sativa meal to the diet of lambs at rate of 10 and $20 \%$ improved the digestibility of crude protein. Similarly, Khattab et al. (2011) informed that calves fed ration added with black seed oil had better nutrient digestibility compared to calves fed free black seed oil diet. However, Cherif et al. (2018) found that the enrichment diets of lambs with Nigella seeds did not affect $(\mathrm{P}<0.05)$ the apparent digestibility of DM, OM, CP and NDF of these diets. Also, Awadalla (1997) found that replacing sunflower meal-protein at 0,50 and $100 \%$ by black cumin seed-meal in the concentrate mixture of growing sheep not significantly effected on nutrient digestibility.

Table (4). Effect of substituted cotton seed meal by $N$. sativa meal in rams ration on nutrient digestibility, \%

\begin{tabular}{|c|c|c|c|c|}
\hline \multirow{2}{*}{ Item } & \multicolumn{3}{|c|}{ Treatment } & \multirow{2}{*}{ P-value } \\
\hline & Control & $\mathrm{T} 1$ & $\mathrm{~T} 2$ & \\
\hline Dry matter, DM & $64.35^{\mathrm{c}} \pm 1.81$ & $70.23^{\mathrm{b}} \pm 1.05$ & $76.51^{\mathrm{a}} \pm 0.87$ & 0.005 \\
\hline Organic matter, OM & $65.11^{\mathrm{c}} \pm 1.05$ & $68.80^{\mathrm{b}} \pm 0.88$ & $76.46^{\mathrm{a}} \pm 0.75$ & 0.003 \\
\hline Crude protein, $\mathrm{CP}$ & $70.23^{b} \pm 1.04$ & $73.75^{\mathrm{ab}} \pm 0.99$ & $77.00^{\mathrm{a}} \pm 1.08$ & 0.010 \\
\hline Ether Extract, EE & $66.95^{c} \pm 0.18$ & $70.75^{\mathrm{b}} \pm 1.08$ & $75.72^{\mathrm{a}} \pm 1.40$ & 0.002 \\
\hline Crude fiber, $\mathrm{CF}$ & $54.28^{\mathrm{b}} \pm 0.96$ & $56.69^{\mathrm{ab}} \pm 0.44$ & $58.46^{\mathrm{a}} \pm 0.74$ & 0.020 \\
\hline Nitrogen free extract, NFE & $79.90 \pm 0.92$ & $80.14 \pm 1.92$ & $79.33 \pm 1.44$ & 0.924 \\
\hline
\end{tabular}

\section{Rumen fermentation activities}

As represented in Table 3, partially substitution of cotton seed meal by $N$. sativa meal not affected on rumen $\mathrm{pH}$ and was maintained at 6.2 to 6.4 in all dietary treatment groups. However, ruminal concentrations of NH3-N and total VFAs increased $(\mathrm{P}<0.05)$ with increasing substitution level from 33.3 to $66.7 \%$ for cotton seed meal by $N$. sativa meal as compared with control group. The higher concentration of NH3-N in rumen of lambs receiving $N$. sativa meal may be associated with increasing CP intake (Table 2) or CP digestibility (Table 4). While, the difference of the concentration of NH3-N in the rumen of sheep between groups taking $N$. sativa meal could be the result of the effect of $p$-cymene which is the major element of oil in Nigella seeds (Chaves et al., 2008). Busquet et al. (2006) stated that p-cymene stimulates the microbial deamination activity. In addition, the p-cymene in Nigella oil has an inhibitory effect on bacterial peptidolysis and deamination processes. Ali (2003) found that the concentration of rumen ammonia nitrogen increase with increasing amounts of $N$. sativa meal in the diets of lambs. In the same context, Cherif et al. (2018) reported that the administration of Nigella seeds reduced $(\mathrm{P}<0.01)$ the total number of protozoa in the rumen, but it increased $(\mathrm{P}<0.01)$ the concentration of NH3-N.

The higher value of total VFAs for animals fed $N$. sativa meal in T1 and T2 are in agreement with ElNaggar et al. (2018) and Klevenhusen et al. (2015) they found that, the rumen volatile fatty acids increased $(\mathrm{P}<0.05)$ with increasing the level of $N$. sativa oil of lambs ration from 0.1 and $0.2 \%$ as compared with control group. 
The total number of protozoa was decreased $(\mathrm{P}<0.05)$ gradually with increasing the level of $N$. sativa meal in the diets of lambs $\left(4.70\right.$ and $\left.2.24 \mathrm{vs} .1 .20 \times 10^{6} / \mathrm{ml}\right)$ for $\mathrm{T}_{1}, \mathrm{~T}_{2}$ and CON group, respectively. The smaller number of protozoa in lambs receiving $N$. sativa meal may be due to some ingredients in Nigella such as thymoquinone and thymohydroquinone and these ingredients possess antimicrobial properties (Mohammed and Al-Suwaiegh, 2016). This results agreement with Cherif et al. (2018) they reported that the protozoa population size decreased with addition of $N$. sativa meal to the diets of lambs.

Table (5). Effect of substituted cotton seed meal by $N$. sativa meal in lambs ration on rumen parameters

\begin{tabular}{lllll}
\hline \multirow{2}{*}{ Item } & \multicolumn{3}{l}{ Treatments* } & \\
\cline { 2 - 4 } & Control & T1 & P-value \\
\hline $\mathrm{pH}$ & $6.28 \pm 0.03$ & $6.32 \pm 0.11$ & $6.44 \pm 0.04$ & 0.318 \\
Ammonia, $\mathrm{mg} / 100 \mathrm{ml}$ & $14.50^{\mathrm{c}} \pm 0.44$ & $17.77^{\mathrm{b}} \pm 0.64$ & $23.69^{\mathrm{a}} \pm 1.12$ & 0.005 \\
TVFA, mmol $/ 100 \mathrm{ml}$ & $7.30^{\mathrm{c}} \pm 0.50$ & $8.93^{\mathrm{b}} \pm 0.39$ & $11.47^{\mathrm{a}} \pm 0.51$ & 0.002 \\
Total protozoa count, $\times 10^{6} / \mathrm{ml}$ & $4.70^{\mathrm{a}} \pm 0.177$ & $2.24^{\mathrm{b}} \pm 0.034$ & $1.20^{\mathrm{b}} \pm 0.023$ & 0.002 \\
\hline a, b,c
\end{tabular}

a,b,c Means of the same row in each item with different superscripts are significantly different $(\mathrm{P}<0.05)$.

*T1: substitution $33.3 \%$ of cotton seed meal by $N$. sativa meal. T2: substitution $66.7 \%$ of cotton seed meal by $N$. sativa meal.

\section{CONCLUSION}

Inclusion of $N$. sativa meal as partially substitution of cotton seed meal to diet of lambs improved the body weight, the average daily gain, nutrients digestibility and rumen fermentation activity of growing Farafra lambs. From the previous results it could be concluded that addition of $N$. sativa meal until rate $66.7 \%$ as alternative source for cotton seed meal in diets of sheep may recommended to improve feed utilization and growth performance of growing Farafra sheep.

\section{REFERENCES}

Abdel-Azeem, F., EL-Hommosany, Y.M., Ali, N.G., 1999. Effect of dietary lack seeds supplementation on productive performance and some physiological parameters of growing rabbits. Egypt. Poult. Sci 19, 779-795.

Abdel-Khalek EA (1995) Possibilities of adaptation to ruminants with feeding on non congressional sources of proteins. PhD Thesis, Bulgarian Academy, Sofia.

Abdel-Magid, S.S., R. El-Kady, S.M. Gad and I. Awadalla, 2007.Using cheep and local non-conventional protein meal(Nigella sativa) as least cost rations formula on performanceof crossbreed calves. Int. J. Agric. Biol., 9: 877-880.

Abd El-Ghani, M.H., 2003. Effect of cumin seed meal(Nigella sativa) as feed ingredient in growing lambs. Egypt.J. Nutr. Feeds, 6: 49-57.

Abd El-Rahman HH, Abedo AA, Salman FM, Mohamed, MI and Shoukry, MM (2011). Partial substitution of cumin seed meal by Jatropha meal as a potential protein source for feed. Afr. J. Biotechnol. 10(68): 15456-15461. https://doi.org/10.5897/ajb11.1595

Abu-Dieyeh, Z.H.M., Abu-Darwish, M.S., 2008. Effect of feeding powdered black cumin seeds (Nigella sativa L.) on growth performance of 4-8 week-old broilers. J. Anim. Vet. Adv 3, 286-290.

Abou El-Naga M., 1967. Some metabolic studies on rumen microorganisms. M.Sc. Thesis, Fac. of Agric., Univ. of Alexandria, Egypt.

Aggarwal, B.B., 2009. Molecular targets and therapeutic uses of spices. Google Books. p.259. ISBN 978- 


\section{Abdullah and Farghaly}

981-4468-95-4.

Ali, M.M.E., 2003. Nutritional and Physiological Studies in Ruminants Productive and Reproductive Performance of Lambs Fed Diets Containing Different Proportions of Nigella Sativa Meal. Fac. of Agric. Mansoura University, Egypt M.Sc. Thesis.

AOAC, 2012. Official methods of analysis, Association of Official Analytical Chemists, Gaithersburg, USA, 19th ed.

Awadalla, I.M., 1997. The use of black cumin seed (Nigella sativa) Cake in rations of growing sheep. Egypt J. Nut. Feeds, 1: 243-9

Babayan, V.K., Koottungal, D., Halaby, G.A., 1978. Proximate analysis, fatty acid and amino acid composition of Nigella sativa L. seeds. Journal of Food Science 43, 1314-1315.

Badary OA, Taha RA, Gamal-el-Din AM, Abdel-Wahab MH (2003). Thymoquinone is a potent superoxide anion scavenger. Drug Chem. Toxicol. 26: 87-98. https://doi.org/10.1081/DCT-120020404

Bita A, Rosu AF, Calina D, Rosu L, Zlatian O, Dindere C, Simionescu A (2012). An alternative treatment for Candida infections with Nigella sativa extracts. Eur. J. Hosp. Pharm. 19: 162. https://doi.org/10.1136/ejhpharm-2012-000074.203

Brunton LL (1998). Agents affecting gastrointestinal water flux and motility, digestants and bile acids, The pharmacological basis of therapeutic, 8th ed. Pregman Press.

Busquet, M., Calsamiglia, S., Ferret, A., Kamel, C., 2006. Plant extracts affect in vitro rumen microbial fermentation. J. Dairy Sci. 89, 761-771.

Cherifa, M., H. Ben Salema, Abidib S., 2018. Effect of the addition of Nigella sativa seeds to low or high concentrate diets on intake, digestion, blood etabolites, growth and carcass traits of Barbarine lamb. Small Ruminant Research 158, 1-8.

Chaves, A.V., He, M.L., Yang, W.Z., Hristov, A.N., McAllister, T.A., Benchaar, C., 2008. Effects of essential oils on proteolytic, deaminative and methanogenic activities of mixed ruminal bacteria. Can. J. Anim. Sci. 88, 117-122.

Conway, EJ., 1962. Microdefusion Analysis and Volumetric Error. (5 ${ }^{\text {th. }}$ Ed.) Crosby- Lockwood and Sons Ltd., London.

Daghash HA, Megahed GA, Abd El-Nabi MA (1999). The influence of feeding Nigella sativa seed on semen quality and fertility improvements of bucks with special references to thermal physiological response and some plasma constituents. Egyptian Society of Animal Reproduction and Fertility. Eleventh Annual Conference in Giza, Egypt. pp.26-28.

El-Ghammry, A.A., El-Mallah, G.M., El-Yamny, A.T., 2002. The effect of incorporation yeast culture, Nigella sativa seeds and fresh garlic in broiler diets on their performance. Egyptian Poultry Science 22, 445-459.

El-Rahman, H.H.A., Abedo, A.A., Salman, F.M., Mohamed, M.I., Shoukry, M.M., 2011. Partial substitution of cumin seed meal by Jatropha meal as a potential protein source for feed. African Journal of Biotechnology 10, 15456-15461.

Elmowalid, G., Amar, A.M., Ahmad, A.A.M., 2013. Nigella sativa seed extract: 1. Enhancement of sheep macrophage immune functions in vitro. Research in veterinary science 95, 437-443.

El-Naggar, S., Abou-Ward, G.A., El-Badawi, A.Y., Ali, A.M. 2018. Commercial oil of Nigella sativa as growth promoter in lambs rations. Iraqi Journal of Veterinary Sciences, Vol. 32, No. 2, 199-204.

Faustman, C., Sun, Q., Mancini, R., Suman, S.P., 2010. Myoglobin and lipid oxidation interactions: Mechanistic bases and control. Meat science 86, 86-94.

Guler T, Ertas ON, Kizil M, Dalkilic B, Ciftci M (2007). Effect of dietary supplemental black cumin seeds on antioxidant activity in broilers. Medycyna Wet. 63: 1060-1063.

Guler, T., Ertas, O.N., 2006. The effect of dietary black cumin seeds (Nigella sativa L.) on the performance of broilers. Asian-australasian journal of animal sciences 19, 425-430.

Habeeb, A.A.M., El Tarabany, A.A., 2012. Effect of Nigella sativa or Curcumin on daily body weight gain, feed intake and some physiological functions in growing Zaraibi goats during hot summer season. 
Idris, H. M., E. M., Nabeila and Al-Tayib, O.A. (2014). Effect of commercial oil of Nigella sativa L. seeds on lipids parameters and weight in sheep. The pharma Innovation Journal. 3(7): 87-91

Islam, M.S., Siddiqui, M.N., Sayed, M.A., Tahjib-Ul-Arif, M., Islam, M.A., Hossain, M.A., 2016. Dietary effects of buckwheat (Fagopyrum esculentum) and black cumin (Nigella sativa) seed on growth performance, serum lipid profile and intestinal microflora of broiler chicks. South African Journal of Animal Science 46, 103-111.

Jamroz D, Kamel C (2002). Plant extracts enhance broiler performance. In non-ruminant nutrition; antimicrobial agents and plant extracts on immunity, health and performance. J. Anim. Sci. 80: 41.

Kanter, M., Meral, I., Dede, S., Cemek, M., Ozbek, H., Uygan, I., Gunduz, H., 2003. Effects of Nigella sativa L. and Urtica dioica L. on lipid peroxidation, antioxidant enzyme systems and some liver enzymes in CCl4- treated rats. Journal of Veterinary Medicine Series A 50, 264-268.

Khattab HM, El - Basiony AZ, Hamdy SM, Marwan AA (2011). Immune response and productive performance of dairy buffaloes and their offspring supplemented with black seed oil. Iran. J. Appl. Anim. Sci. 1(4): 227-234.

Khan, M.A.U., Ashfaq, M.K., Zuberi, H.S., Mahmood, M.S., Gilani, A.H., 2003. The in vivo antifungal activity of the aqueous extract from Nigella sativa seeds. Phytotherapy Research: An International Journal Devoted to Pharmacological and Toxicological Evaluation of Natural Product Derivatives 17, 183-186.

Klevenhusen, F.D.K, Sizmaz Ö, Wimmer S, Muro-Reyes A, Khiaosa-Ard R, Chizzola R,Zebeli Q .2015. Effects of black seed oil and Ferulaelaeochytris supplementation on ruminal fermentation as tested invitro with the rumen simulation technique (Rusitec). Anim Prod Sci.2015: http://dx.doi.org/10.1071/AN13332.

Koracevic, D., Koracevic, G., Djordjevic, V., Andrejevic, S., Cosic, V., 2001. Method for the measurement of antioxidant activity in human fluids. Journal of clinical pathology 54, 356-361.

Lewis JJ (1980). Lewiss pharmacology, fifth ed. Churchill Livingston, London. Pp. 656-657.

Makkar, H.P.S., Francis, G., Becker, K., 2007. Bioactivity of phytochemicals in some lesser-known plants and their effects and potential applications in livestock and aquaculture production systems. animal 1 , 1371-1391.

Mohamed, I.M., 2007. Evaluation of growth performance for growing Maghraby camel fed on unconventional feed. Int. J. Agri. Biol 9, 18-21.

Mohammed, A.A., Al-Suwaiegh, S. B. 2016. Effects of Nigella sativa on Mammals' Health and Production. Advances in Animal and Veterinary Sciences. 4 (12),|630-636.

Mahmoud AEM, Bendary MM (2014). Effect of whole substitution of protein source by Nigella sativa meal and sesame seed meal in ration on performance of growing lambs and calves. Global Vet. 13(3): 391396.

NRC., 2006. Nutrient Requirment of Sheep. National AcademyPress, Washington DC., USA.

Omar ME (2003) Influence of substituting concentrate feed mixture protein with Nigella sativa meal protein on the productive performance of growing rabbits. MSc thesis, Faculty of Agriculture, Mansoura University, Egypt.

Retnani,Y., K. G., Wiryawan, L., Khotijah, N. N.,Barkah, R A., Gustian and I R., Dermawan (2019): Growth Performance, Blood Metabolites and Nitrogen Utilizationof Lambs Fed with Nigella sativa Meal. Pak. J. Nutr., 18 (3): 247-253.

Warner, A.C.I., 1964. Production of volatile fatty acids in the rumen: methods of measurement. Nutrition Abstract Review, 34, 339.

Zanouny, A.I., Abd-el-Moty, A.K.I., El-Barody, M.A.A., Sallam, M.T., Abd-el-Hakeam, A.A., 2013. Effect of supplementation with Nigella sativa seeds on some blood metabolites and reproductive performance of Ossimi male lambs. Egyptian Journal of Sheep and Goat Sciences 8, 47-56. 
تاثير الاستبدال الجزئى لكسب بذرة القطن بكسب حبة البركة على هضم العناصر الغذائيه، تخمرات الكرش، بض خصائص الام و أداء الحملان النامية الكبنة

\author{
محمود عبد اللطيف عحم عبد الله و محسن محم فرغلى \\ قسم الانتاج الديوانس- كلية النزراعة - جامعة أسيوط ـ مصر فئر
}

أجريت هذه الدراسة لتقييم تاثثير الإستبدال الجزئى لكسب بذرة القطن فى المخلوط المركز بكسب حبة البركة على هضم العناصر



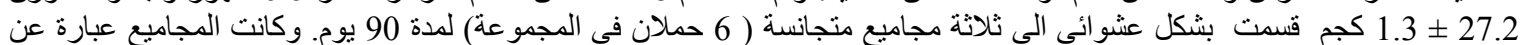



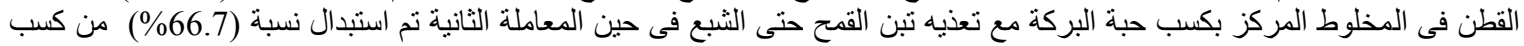

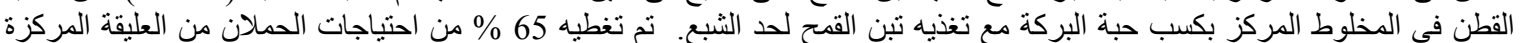

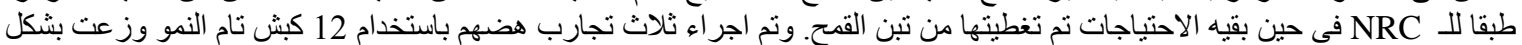

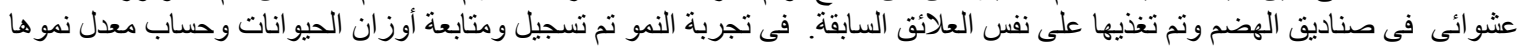

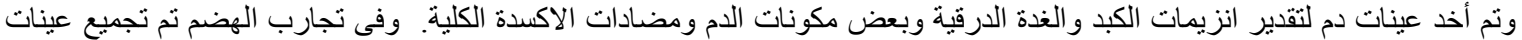

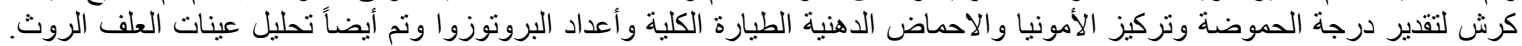

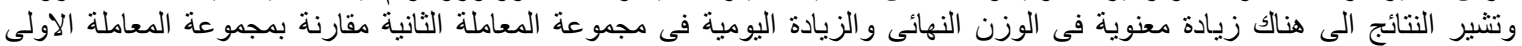

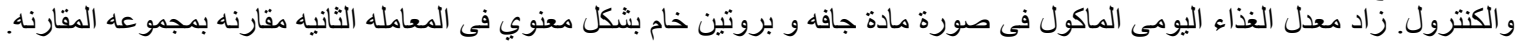

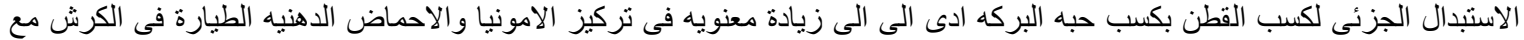

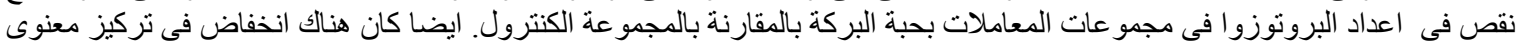

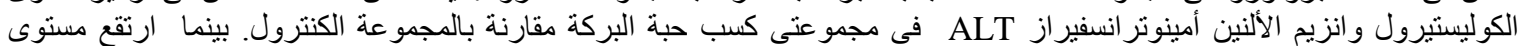

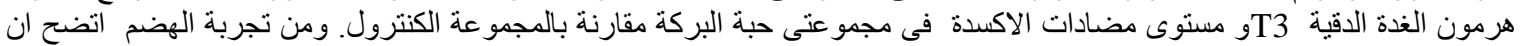

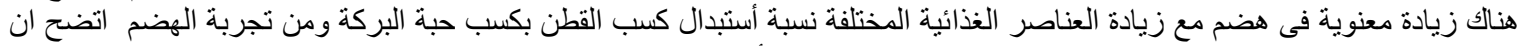

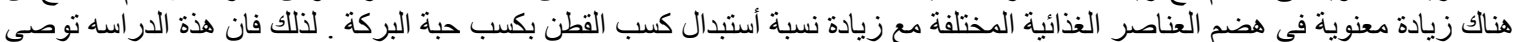

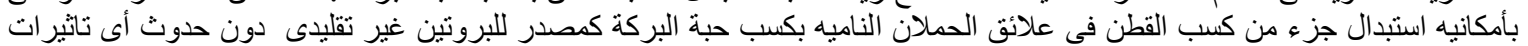
سلبية على أداء الحملان النامبهاء

الكلمات المفتاحية: كسب حبة البركة ، هضم العناصر الغذائيه، تخمرات الكرش، خصائص الدم ، أداء الحملان. 